\title{
Overview on the Utilization of Quarry Dust as a Replacement Material in Construction Industry
}

\author{
Nur Jannah Abdul Hamid, Aeslina Abdul Kadir ${ }^{1, *}$ Nor Amani Filzah Mohd \\ Kamil $^{1}$, Mohd Ikhmal Haqeem Hassan ${ }^{1}$
}

\author{
${ }^{1}$ Department of Civil and Environmental Engineering \\ Universiti Tun Hussein Onn Malaysia, Parit Raja, 86400 Batu Pahat, Johor, MALAYSIA.
}

Received 01 January 2018; accepted 15 April 2018, available online 07 May 2018

\begin{abstract}
In line with economic development of the country, demand of raw materials for the construction, building and manufacturing sectors are also increasing. Concrete is a great significance that contributes to every construction practices. Concrete is the most widely used construction material in the world because of its ability to get cast in any form and shape. The strength and durability of concrete can be changed by utilizing suitable improvements in its ingredients such as cementitious material, aggregates and water. One of the raw materials used to produce conventional concrete is river sand which has significantly become very costly and becoming scarce due to river bed depletion therefore alternative material is in need. On the other hand, the growth of human population has led to concerns in solid waste management prior to major environmental problems that arose due to urbanization and industrial activities thus lead to its utilization in building material. There are different types of waste materials being used in the construction industry such as stone quarry dust, fly ash, rice husk, clay brick, metakaolins, palm oil fuel ash, bamboo leaf ash, volcanic ash, ground nut husk ash, waste glass, slurry glass powder, quarry dust and marble dust powder. Nevertheless, this paper only reviews on quarry dust as sand replacement in construction industry.
\end{abstract}

Keywords: Sand replacement, strength, workability, waste management, environmental problem

\section{Introduction}

The globalization had led the developing of the construction of buildings, express highways, power projects and industrial structures in order to fulfill human needs. Concrete is a great significance that contributes to every construction practices. Concrete is a composite construction material made primarily with aggregate, cement and water Batayneh et al., [1]. It likewise replaces old construction materials, which are brick and masonry. One of the raw materials used to produce conventional concrete is river sand which has significantly become very costly and becoming scarce due to river bed depletion Alexander et al., [2].

Sand is a fundamental natural source for any society. Regardless of society's increasing reliance on sand, there are real challenges that this industry needs to consider due to limited sand resources, illegal mining and environmental impact of sand mining (Marius and Gavriletea [3].The mining for sand river source plays an important role in the development of construction industry. Consequently, it causes to the raise of issues related to environmental concerns which are the depletion of non-renewable resources and endanger the environment if possible actions not been taken by the authorities.
According to Appukutty and Murugesan [4], there were shortages of natural river sand for construction due to over exploitation from sources, the inability of the nature to replace it and increasing pressures from local bodies. In order to protect the environment, either replacement or substitution for sand is warranted during this decade and for future. There are many attempts by many researches in finding the suitable material to be incorporating in concrete as partial or fully replacement for natural river sand. Among the wastes materials are metakaolins [5], rice husk [6], ground nut husk ash [7], volcanic ash [8], fly ash [9], slurry glass powder [10], marble dust powder [11], bamboo leaf ash [12], palm oil fuel ash [13] and quarry dust [15].

Presently, quarrying operations for aggregates supply in the concrete production are used extensively in the construction industry and are considered important for the economy development Galetakis et al., [16], For this reason, quarrying had harmed the environment by the emission of dust dispersed in air, water and soil. The accumulated dust during aggregates production shall be utilized or being incorporated as wastes recycle in construction industry. Henceforth, quarrying industries had facing a major issue of environmental management which had encouraged them to find the alternatives in assessing the potential impact of their operation in order 
to meet the standards for waste disposal that specified by laws and regulations. It is beneficial for the quarrying and construction industry as the accumulated dust during aggregates production can be utilized as replacement for other materials.

In such a situation, the quarry dust can be an economical alternative to the river sand. The research on sand replacement for concrete industry needs to be found under those circumstances which are the availability, cost and environmental impact. The investigation on the hardened and durable properties of concrete utilize quarry dust are conducted by many researchers nowadays. Basically, to overcome the crisis, partial replacement of sand with quarry dust can be an economic alternative choice. In addition, the use of quarry dust as the complete replacement of natural river sand which acts as the fine aggregate could cut the cost in concrete production. The quarry dust should be used in construction works as the cost of construction would be saved and the natural resources would be utilized efficiently.

\section{Quarry Dust}

Rapid growth of the construction industry has occured during the last decade. Correspondingly, the demand for aggregates for the concrete production is increasing. Waste materials such as fine quarry dust are generated in the same scale of urbanization and industrialization. Quarry dust is crushed dust obtained from stone boulders in stone crushers during the production of coarse aggregates Naganathan et al., [17]. As well quarry dust is a by-product from crushing process during quarrying activities. It is used as substitute to sand to make concretes, which are believed to be stronger and more durable than the regular concrete materials by Gibson [18]. Beside, quarry rock dust can be defined as residue, tailing or other non-voluble waste after material after the extraction and processing of rocks to form fine particles less than $4.75 \mathrm{~mm}$ Ilangovana et al., [19]. The quarry sand is the coarse fraction of the quarry powder and is being used as the fine aggregate in place of river sand concrete production Galetakis et al., [16].

The quarry dust consists of excess fines and is dumped in open fields that cause environmental problem. Raman et al., [20], added the fine quarry dust fraction is commercially unused material. Due to the scarcity of disposal land in the proximity of industries and growing environmental concerns, the disposal of the dust becomes extremely costly Tay et al., [21]. Therefore, it is desirable to obtain cheap, environmentally friendly substitute for river sand which is quarry dust that is preferably by products.

Recently, many researches had done studies on quarry dust to be used as an effective filler material in concrete instead of fine aggregate. Some studies were reviewed by Chandana et al., [22], on physical and chemical properties as per listed in Indian Standard. Table 1 and Table 2 show the physical properties and chemical properties of quarry dust and natural sand respectively.
Table 1 shows the physical properties of quarry dust and natural sand [19]

\begin{tabular}{|l|c|c|l|}
\hline Property & Quarry Dust & $\begin{array}{l}\text { Natural } \\
\text { Sand }\end{array}$ & Test method \\
\hline $\begin{array}{l}\text { Specific } \\
\text { gravity }\end{array}$ & $2.54-2.60$ & 2.60 & $\begin{array}{l}\text { IS2386(Part } \\
\text { III)- 1963 }\end{array}$ \\
\hline $\begin{array}{l}\text { Bulk density } \\
\text { (kg/m3) }\end{array}$ & $1720-1810$ & 1460 & $\begin{array}{l}\text { IS2386(Part } \\
\text { III)- 1963 }\end{array}$ \\
\hline $\begin{array}{l}\text { Absorption } \\
(\%)\end{array}$ & $1.20-1.50$ & Nil & $\begin{array}{l}\text { IS2386(Part } \\
\text { III)- 1963 }\end{array}$ \\
\hline $\begin{array}{l}\text { Moisture } \\
\text { Content (\%) }\end{array}$ & Nil & 1.50 & $\begin{array}{l}\text { IS2386(Part } \\
\text { III)- 1963 }\end{array}$ \\
\hline $\begin{array}{l}\text { Fine particles } \\
\text { less than } \\
0.075 \text { mm (\%) }\end{array}$ & $12-15$ & 6 & $\begin{array}{l}\text { IS2386(Part } \\
\text { III)- 1963 }\end{array}$ \\
\hline Sieve analysis & Zone-II & Zone-II & IS 383-1970 \\
\hline
\end{tabular}

Table 2 shows the typical chemical properties of quarry dust and natural sand [19]

\begin{tabular}{|c|c|c|c|}
\hline Constituents & $\begin{array}{l}\text { Quarry } \\
\text { Dust (\%) }\end{array}$ & $\begin{array}{l}\text { Natural } \\
\text { Sand (\%) }\end{array}$ & $\begin{array}{l}\text { Test } \\
\text { method }\end{array}$ \\
\hline $\mathrm{SiO} 2$ & 62.48 & 80.78 & \multirow{9}{*}{$\begin{array}{c}\text { IS } \\
4032- \\
1968\end{array}$} \\
\hline $\mathrm{Al} 2 \mathrm{O} 3$ & 18.72 & 10.52 & \\
\hline $\mathrm{Fe} 2 \mathrm{O} 3$ & 6.54 & 1.75 & \\
\hline $\mathrm{CaO}$ & 4.83 & 3.21 & \\
\hline $\mathrm{MgO}$ & 2.56 & 0.77 & \\
\hline $\mathrm{Na} 2 \mathrm{O}$ & Nil & 1.37 & \\
\hline $\mathrm{K} 2 \mathrm{O}$ & 3.18 & 1.23 & \\
\hline $\mathrm{TiO} 2$ & 1.21 & Nil & \\
\hline Loss of ignition & 0.48 & 0.37 & \\
\hline
\end{tabular}

Based on the properties, quarry dust possessed specific gravity which almost similar to the natural sand. Hence the use of quarry dust in concrete is desirable as its benefits such as useful disposal of by products, reduction of river sand consumption as well as increasing the strength parameters and increasing the workability of the concrete Priya et al., [23]. In addition, quarry dust is recognized to help in increasing the strength of concrete over the concrete made with same quantities of river sand. Somehow, it causes a reduction in the workability of concrete when the percentage of quarry dust is increased Mir et al., [24]. Though the advantage of using quarry dust as sand replacement is the specific gravity, as it depends on the nature of the rock from which it is processed and the variation is lesser by Ukpata et al., [25]. Indeed the shrinkage is more in when compared to that of the natural sand river Ilangovana et al., [19]. Moreover, the water absorption is present in the concrete so that will increase the water addition to the dry mix by Sivakumar and Prakash [26].

As much as sustainability has become priority all over the world, especially in the production of concrete hence the utilization of these wastes apparently is such a viable attempt to be realized. Furthermore, the environmental exploitation could be reduced as the sand river mining will be minimized. Quarry dust has been proposed as an alternative to river sand that gives additional benefit to concrete. It is known to increase the strength of concrete over the normal concrete, even 
though it will affect in the reduction of the workability of the concrete.

\section{Overview of Sand Replacement with Quarry Dust in Construction Industry}

The attention on the utilization of quarry dust as a fine aggregate in concrete had grows tremendously among the researchers due to the advantages own by quarry dust. Compared to conventional concrete, the concrete incorporated with quarry dust has higher durability under sulphate attack and under acid action. Besides, the effects on the elastic modulus property are good and the fine quarry dust tends to increase the amount of super plasticizers needed for the quarry mixes in order to achieve the rheological properties for the concrete. Basically, quarry dust has rough, sharp and angular particles, thus formed a gain in strength due to better interlocking by Garg and Jain [27].

According to Naganathan et al., [17], quarry dust has been used successfully in concrete, pavement construction and in controlled low-strength materials (CLSM). Naganathan et al., [17], added that the addition of quarry dust does not affect the setting time but it reduces the water demand for constant flow consistency. Moreover, it can increase the fresh density and hardened density of the concrete. From the properties reported, it can be concluded that the utilization of quarry dust in CLSM has potential in enhancing the performance of the mixtures.

Sureshchandra et al., [28], studied the effect of replacement of sand by quarry dust in hollow concrete block for different mix proportions. The objective of the study is to indicate the properties of hollow concrete blocks produced by the quarry dust as sand replacement. The results showed the hollow concrete blocks sand production can be replaced partially by $50 \%$ by quarry dust instead of complete replacement. It seemed that the blocks with $50 \%$ replacement performs better than blocks which are conventionally prepared using natural sand. Moreover, the hollow concrete blocks can be used in load bearing masonry structures as other option in construction industry.

In addition, Sukesh et al., [29], gave attention about partial replacement of sand with quarry dust in concrete. The results showed the replacement of the sand by quarry dust gives an improvement in the compressive strength value. However, instead of the increases percentage of quarry dust replaced the sand, the workability of the concrete is decreasing due to the absorption of the water by quarry dust. The specific gravity recorded for both for the natural river sand and quarry dust is almost same. In this study, the physical properties like particle size distribution and bulking variation are the parameters which affect the mix design of the concrete. At the standard water-cement ratio, the workability is very less and more water is required for making the concrete with partial replacement to form a zero slump. From the outcomes, the ideal percentage of the replacement of sand with the quarry dust is $55 \%$ to $75 \%$ in case of compressive strength. Otherwise, for further increasing of the percentage of replacement, adding of the fly ash along with the quarry dust can be made useful so that $100 \%$ replacement of sand can be achieved.

Previously Charkha [30], studied on partially replaced conventional materials with quarry dust and fly ash for the production of concrete. From the results obtained, the physical properties such as rough texture and angular shape of quarry dust particles with inclusion of fly ash cause the concrete's workability to be reduced. On the other hand, the satisfactory mechanical properties recorded up to $10 \%$ replacement of cement by fly ash and $30 \%$ replacement of sand by quarry dust with $0.5 \%$ of superplasticizer. The study showed improvement in mechanical properties of the concrete when replacing the cement and sand by wastes material which will be advantageous in term of waste disposal for the environment.

Furthermore, Balamurugan and Perumal [31], discussed the use of quarry dust as a sand replacement material for concrete production which showed a maximum increase in compressive strength $(19.18 \%)$, tensile strength $(21.43 \%)$ and flexural strength $(17.8 \%)$ at $50 \%$ sand replacement by quarry dust. This result gives clear view that quarry dust can be utilized in concrete mixtures as a good substitute for natural river sand at $50 \%$ replacement. The need in replacing the natural sand river in concrete's ingredients with additional strength than control concrete can be solved by the utilizing of quarry dust obviously.

As for Ilangovana et al., [19], the strength and durability properties of concrete containing quarry rock dust as fine aggregate was studied. Based on the results, compared to the conventional concrete, the durability of quarry concrete under sulphate and acid action is higher. Nevertheless, the permeability of quarry concrete is less compared to that of the conventional concrete. At $100 \%$ replacement of sand by quarry dust strength values are same or better than the ones of the control concrete made with natural sand. Thus the utilization of quarry dust in concrete is highly expected to give more strength and durability to the concrete production.

The compressive strength of concrete produced using lateritic sand and quarry dust as fine aggregate by Ukpata et al., [25], showed the workability for both concrete have the same trend with normal concrete. From the findings, the workable concrete produced at the proportion of $25 \%$ laterite to $75 \%$ quarry dust and $50 \%$ laterite to $50 \%$ quarry dust with 0.6 of water to cement ratio. For normal concrete, mostly the compressive strength was found to increase with age. The compressive strength recorded for the concrete at the 28 days was found to range from 17 to $34 \mathrm{~N} / \mathrm{mm}^{2}$ for different mixtures. It indicated that the proportion of $25 \%$ laterite to $75 \%$ quarry dust will produce higher compressive strength values based on the study conducted which is very anticipated to be used in concrete production.

On top of that, Lim et al., [32], investigated the feasible utilization of quarry dust as other option to river sand in the production of lightweight foamed concrete 
(LFC). In this study, quarry dust was used to replace sand at ratios of $75 \%$ and $100 \%$, and four different of water to cement ratio $(\mathrm{w} / \mathrm{c})$ of $0.52,0.54,0.56$ and 0.58 . For a given $\mathrm{w} / \mathrm{c}$ ratio, it was found that the use of high volume quarry dust could reduce the fluidity, yet increase the compressive strength and the thermal conductivity of LFC. However, there was no significant decrease of compressive strength recorded with the increase of $\mathrm{w} / \mathrm{c}$ ratio during the experiment done, probably due to the reduction of foam volume requirement in the system. The final results showed that the LFC containing quarry dust possessed less environmental effect in terms of lower energy consumption and lower amount of greenhouse gases emission which will benefit the construction industry.

On the other hand, Krishnamoorthi and Kumar [33], studied the properties of concrete mixture by simultaneous utilize of fly ash and quarry dust. They produced the concrete replacing cement of $10 \%, 15 \%$ and $20 \%$ by fly ash while using quarry dust as fine aggregate to compare with the conventional concrete. They had found that the increase in quarry dust resulted in decrease of slump values. Meanwhile, the decrease in workability by the addition of quarry dust is reduced by the addition of fly ash. However, from the outcomes, the compressive strength of quarry concrete is less than the sand concrete probably due to the poor grading of particles in quarry dust, excessive flakiness of the flexural and split tensile strength which is quite equal to conventional concrete. Thus this make the incorporation of fly ash and quarry dust could help in workability even though there might be slightly decreased in mechanical properties of the concrete.

As for Lohani et al., [34], the use of quarry dust as partial replacement of sand in concrete production was investigated. Basically, the concrete does not give adequate workability and tends to segregate with the increase of quarry dust. It is due to the flaky particles shape and higher percentage of fines quarry dust. The study showed by the increase in dust content up to $30 \%$, the compressive strength of concrete will increase but if the dust content was beyond $30 \%$, the compressive strength will decrease gradually. On the other hand, at $20 \%$ replacement of fine aggregate, the split tensile strength recorded is at maximum. While for water absorption percentage of quarry dust concrete decreased for dust content from $0 \%$ to $20 \%$ and then it started to increase for $30 \%, 40 \%$ and $50 \%$ of dust contents. The best option identified from the study is $30 \%$ of replacement of sand by quarry dust which give the optimum performance in properties of concrete.

Likewise, Raman et al., [35], studied the suitability of quarry dust as partial substitute for sand in highstrength concrete (HSC) containing rice husk ash (RHA). The study used two grades of HSC mixes, which designed with and without the incorporation of RHA, to achieve $60 \mathrm{MPa}$ and $70 \mathrm{MPa}$ at 28 days. Quarry dust was used as sand replacement in the mixes containing RHA, in quantities ranging from $10 \%$ to $40 \%$. The results showed the mixes containing $20 \%$ quarry dust were chosen as the optimum mix design for concrete which would then undergo further evaluation of their strength and mechanical properties up to one year. However, the results then suggest that even though the utilization of quarry dust as partial replacement come out in some minor negative effects, include the compressive strength and other mechanical properties of concrete. Even so, these situations can be compensated by a good mix design and by the incorporation of RHA. The findings marked that quarry dust can be used as a viable replacement material to sand in order to produce high strength RHA concrete in construction industry.

Rai et al., [36], investigated the effect of fly ash with quarry dust as fine aggregate on mortar mixtures. The findings showed for a given water to cement ratio, an increase in fly ash content caused the drop in compressive strength of the mortar. While by the addition of fly ash, the decrease in early strength was enhanced by the increase of quarry dust. Thus from the investigation, it can be justify that quarry dust could improve the performance of mortar mixtures incorporated with fly ash in the form of compressive strength.

It is reported Sureshchandra et al., [28], investigated on replacing sand by quarry dust for the hollow concrete blocks. In the study, 50\% partial replacement of sand by quarry dust for the blocks had indicated a better performance than the ones with complete sand replacement. Additionally, Venkatarishnaian and Rajkumar [37], studied the properties of waste plastic fibre reinforced concrete when quarry dust is used to replace natural sand. The maximum workability and strength values were recorded when $30 \%$ of quarry dust used to replace sand. Meanwhile, after 30\% replacement of quarry dust the strength values decreased. Therefore, by $50 \%$ and $30 \%$ replacement of sand by quarry dust is the optimum percentage for hollow concrete blocks and waste plastic fibre concrete respectively.

According to Shruti et al., [38], the mechanical behaviour of M20 grade concrete was studied with quarry dust as sand replacement by $25 \%, 50 \%, 75 \%, 100 \%$, ground granulated blast furnace slag (GGBS) as cement replacement by $20 \%, 30 \%, 40 \%, 50 \%$ and $60 \%$ with plain cement concrete. The optimum replacement of sand by quarry dust recorded from the findings was at $50 \%$. The split tensile strength carried out on specimen with $50 \%$ quarry dust replacement on sand and 60\% GGBS replacement of cement gave an increase value linearly. Besides, the flexural strength conducted with the same proportion showed an increase value but it did not show the linear value of increased. From the outcome, the 50\% or quarry dust and $60 \%$ of GGBS by replacement were selected to be incorporated in the concrete in order to achieve maximum mechanical properties.

Markedly, the advantages of utilization of by products or aggregated obtained from waste materials are highlighted in the aspects of reduction in environmental load, waste management cost, reduction of production cost as well as augmenting the quality of concrete itself. Reutilization of quarry dust in concrete industry had received serious attention from the construction 
practitioners as an environmental friendly and sustainable solution for waste disposal from the quarrying industries.

\section{Conclusion}

Based on this overview, the further researches on aspects related to the utilization of waste materials for construction materials are looking forwards to give benefits in term of durability of the concrete as well as conserving the environment. Overall, the $50 \%$ of quarry dust was used as partial sand replacement in construction materials but, beyond of this percentage, the compression strength value is reducing and affected the workability of the concrete. Thus, the reutilizing of quarry dust from quarrying industry is such a sustainable approach in order to comply with future needs of environmental and concrete technology.

\section{References}

[1] Batayneh, M., Marie, I., \& Asi, I. (2007). Use of selected waste materials in concrete mixes. Waste management, 27(12), 1870-1876.

[2] Alexander, M., \& Mindess, S. (2010). Aggregates in concrete. CRC Press.

[3] Gavriletea, M. D. (2017). Environmental Impacts of Sand Exploitation. Analysis of Sand Market. Sustainability, 9(7), 1118.

[4] Appukutty, P., \& Murugesan, R. (2009). Substitution of quarry dust to sand for mortar in brick masonry works. International Journal on Design and Manufacturing Technologies, 3(1), 5963.

[5] Joe K. Cochran, Joy M. Justice, 2005 "Evaluation of metakaolins for use as supplementary cementitious materials".

[6] Makarand Suresh Kulkarni, Paresh Govind Mirgal, Prajyot Prakash Bodhale3, S.N. Tande, August 2014, "Effect of Rice Husk Ash on Properties of Concrete" Volume I, Krishi Sanskriti Publications.

[7] Egbe-Ngu Ntui Ogork, Okorie Austine Uche, Augustine Uche Elinwa, July 2014, "A Study on Groundnut Husk Ash (GHA)-Concrete under Acid Attack", International Journal of Modern Engineering Research, Volume IV.

[8] El-Sharif M. Ibrahiem, Salih A. M. Ahmed, March 2014 "Evaluation of Jebel Marra Volcanic Ash as Supplementary Cementitious Material for Use in Blended Cements", IOSR Journal of Engineering, Volume IV.

[9] Abdul Karim Shah, Zeenat Muhammad Ali, Abdul Jabbar Laghari and Syed Farman Ali Shah, 2009 "Utilization of Fly Ash as Low-Cost Adsorbent for the Treatment of Industrial Dyes Effluents- A Comparative Study".

[10] Patricija Kara, August 2013, "The Influence of Waste Glass Slurry on the Properties of Concrete", International Journal of Application or Innovation in Engineering \& Management, Volume II

[11]P.A. Shirule, Ataur Rahman, Rakesh D. Gupta,
2104, "Partial Replacement of Cement with Marble Dust Powder", International Journal of Advanced Engineering Research and Studies.

[12]P. Asha, A. Salman, R. Arun Kumar, August 2014 "Experimental Study on Concrete with Bamboo Leaf Ash", International Journal of Engineering and Advanced Technology, Volume-III.

[13] Sooraj V.M, June 2013 "Performance of concrete by using palm oil fuel ash (pofa) as a cement replacement material", International Journal of Scientific and Research Publications, Volume 3.

[14] A.V.S.Sai. Kumar and Krishna Rao, 2014, “A study on strength of concrete with partial replacement of cement with quarry dust and Metakaolin", International Journal of Innovative Research in Science, Engineering and Technology.

[15] R.Ilangovana, N.Mahendrana and K.Nagamanib, Strength and durability properties of concrete containing quarry dust as fine aggregate, Pg.No. 20 to 26, ARPN Journal of Engineering and Applied Science, Vol.3,No.5, October 2008.

[16] Galetakis, M., Alevizos, G., \& Leventakis, K. (2012). Evaluation of fine limestone quarry byproducts, for the production of building elementsAn experimental approach. Construction and building materials, 26(1), 122-130.

[17] Naganathan, S., Razak, H. A., \& Hamid, S. N. A. (2012). Properties of controlled low-strength material made using industrial waste incineration bottom ash and quarry dust. Materials \& Design, 33, 56-63.

[18] Gibson, R. F. (2016). Principles of composite material mechanics. CRC press.

[19] Ilangovana, R., Mahendrana, N., \& Nagamanib, K. (2008). Strength and durability properties of concrete containing quarry rock dust as fine aggregates. In ARPN Journal of Engineering and Applied science.

[20] Raman, S. N., Ngo, T., Mendis, P., \& Mahmud, H. B. (2011). High-strength rice husk ash concrete incorporating quarry dust as a partial substitute for sand. Construction and Building Materials, 25(7), 3123-3130.

[21] Tay, J. H., Hong, S. Y., \& Show, K. Y. (2000). Reuse of industrial sludge as pelletized aggregate for concrete. Journal of Environmental Engineering, 126(3), 279-287.

[22] Sukesh, C., Krishna, K. B., Teja, P. S. L. S., \& Rao, S. K. (2013). Partial replacement of sand with quarry dust in concrete. International Journal of Innovative Technology and Exploring Engineering, 2(6), 254-258.

[23] Priya, R. R., Athithan, A. K. K., \& Ramya, E. Experimental Investigation of Partial Replacement of Fine Aggregate by Quarry Dust in Concrete With Steel Powder.

[24] Mir, A. H. (2015). Replacement of Natural Sand with Efficient Alternatives: Recent Advances in Concrete Technology. Vol. 5,(Part 3).

[25]Ukpata, J. O., Ephraim, M. E., \& Akeke, G. A. 
(2012). Compressive strength of concrete using lateritic sand and quarry dust as fine aggregate. ARPN journal of engineering and applied sciences, 7(1), 81-92.

[26] Sivakumar, A., \& Prakash, M. (2011). Characteristic studies on the mechanical properties of quarry dust addition in conventional concrete. Journal of civil engineering and construction technology,2(10), 218-235.

[27] R. Venkatakrishnaiah, P. Rajkumar, Effect of quarry dust on waste plastic fiber reinforced concrete - an experimental study, Res. Civ. Environ. Eng. 1 (4) (2013) 234-238.

[28] Sureshchandra, H. S., Sarangapani, G., \& Kumar, B. N. (2014). Experimental investigation on the effect of replacement of sand by quarry dust in hollow concrete block for different mix proportions. International Journal Of Environmental Science And Development, 5(1), 15.

[29] Sukesh, C., Krishna, K. B., Teja, P. S. L. S., \& Rao, S. K. (2013). Partial replacement of sand with quarry dust in concrete. International Journal of Innovative Technology and Exploring Engineering, 2(6), 254-258.

[30] Charkha, S. D. (2013). Experimental investigation of M30 design mix concrete with partial replacement of conventional ingredients. Int. J. Res. Civ. Eng. Archit. Des, 1(2), 38-45.

[31] Balamurugan, G., \& Perumal, P. (2013). Behaviour of concrete on the use of quarry dust to replace sand-an experimental study. BEHAVIOUR, 3(6).

[32]Lim, S. K., Tan, C. S., Li, B., Ling, T. C., Hossain, M. U., \& Poon, C. S. (2017). Utilizing high volumes quarry wastes in the production of lightweight foamed concrete. Construction and Building Materials, 151, 441-448.

[33] Krishnamoorthi, A. (2013). Properties of green concrete mix by concurrent use of fly ash and quarry dust. IOSR Journal of Engineering, 3, 48-54.

[34] Lohani, T. K. (2012). Optimum utilization of Quarry dust as partial replacement of sand in concrete. International Journal of Applied Science and Engineering Research.

[35] Raju, M. R., Vivek, K. V., Reddy, T. S. S., \& Reddy, P. S. (2011). Study of Properties of SCC using 'Quarry Dust'and 'Fly Ash. International Journal of Engineering Sciences ResearchIJESR, 2(04).

[36] Menadi, B., Kenai, S., Khatib, J., \& Aït-Mokhtar, A. (2009). Strength and durability of concrete incorporating crushed limestone sand. Construction and Building Materials, 23(2), 625-633.

[37] Rai, B., Kumar, S., \& Satish, K. (2014). Effect of fly ash on mortar mixes with quarry dust as fine aggregate. Advances in materials Science and Engineering, 2014.

[38] Shruthi, R., Vimalanandan, M. G., \& Selvan, D. S.
S. (2016). Mechanical Behaviour Of Concrete Made With Quarry Dust And GGBS. Analysis, 10, $150 \mathrm{~mm}$. 